\title{
CO-57: AN ELECTROPHORETIC INVESTIGATION ON THE PROPERTIES IN THE ULTRADILUTED AQUEOUS SOLUTIONS
}

\author{
Bontchev $^{1}$ G. D., G. A. Bojikov², M. V. Milanov ${ }^{3}$ \\ ${ }^{1}$ Prof. P. Stoyanov Varna University of Medicine, ${ }^{2}$ Joint Institute of Nuclear Research (JINR) - \\ Dubna, Russia and ${ }^{3}$ Institute of Nuclear Research and Nuclear Energy - Sofia, Bulgarian Academy \\ of Sciences
}

Reviewed by: Assoc. Prof. M. Stancheva, PhD

\begin{abstract}
Radioactive Cobalt is used in nuclear medicine mainly for radiotherapy as well as radiodiagnostics. Radiotherapeutic application usually includes extracorporeal gamma irradiation by means of nuclide Co-60, which spectrum is rich of very high energy gamma quanta. At the contrary, the isotope Co-57 emits merely low energy gamma quanta, thus represents a soft gamma emitter, highly suitable for the clinical radiodiagnostics. In-vivo treatment with the radioactive Cobalt drugs, however, provokes the risk of patient's blood and tissue radioactive contamination, due to appearance of simple Cobalt ions and their insoluble forms. Therefore, it could be of a practical interest to know chemical properties as well as the behavior of the hydrated Cobalt ions in water solutions at microconcentrations as low as $10^{-6}-10^{-7}$ mol..$^{-1}$. In this paper the highly suitable electromigration technique is discussed and applied. A set of collected radioanalytical data, including values of parameters such as ion mobilities, molar volumes, Stocks radii, hydration numbers, diffusion coefficients as well as their temperature dependence in water solutions is presented.
\end{abstract}

Keywords: Co-57, Co-60, radiodiagnostics, electrophoresis, electromigration

\section{INTRODUCTION}

The Cobalt isotopes are widely used in practice for solving many different type of problems. There are two radioactive ${ }_{27} \mathrm{Co}$ isotopes which are of a great importance to the nuclear medicine in particular. At first, we have high-energy gamma emitter Co-60, extremely suitable for sterilization of medical equipment, food irradiation (cold pasteurization) (21) and extracorporeal radiotherapy of cancer, e.g. Kaposi's sarcoma (22), metastatic pinealoma (24), melanocytoma (17), breast cancer (15) etc. At second, there is positron and soft-gamma emitter Co-57, which is commonly used as check sources for medical equipment, as radioactive markers in nuclear medicine diagnosis, for tumor visualization (as a bleomycin complex, Fig. 1) (20) as well as in some medical test, e.g. Schilling's test - as a radiolabel for vitamin B-12 uptake (23).

There should be underlined, that both Cobalt isotopes are relatively long-lived ones, therefore the risk for patient's gamma contamination must not be underestimated, especially in relevance to in-vivo treatment by $\mathrm{Co}-57$ radiopharmaceuticals. As a $d$-chemical element, Cobalt forms an organic complexes which shows a tendency to

Address for correspondence:

G. Bontchev, Dept. of Chemistry, Prof. P. Stoyanov Varna University of Medicine, 55 Marin Drinov Str., BG-9002, Varna, Bulgaria e-mail: gogobg1808@yahoo.com undergo a multistage hydrolytic processes, thus forming insoluble hydroxides, which may lead to in-body radionuclide precipitation, and hence - to internal gamma rays overdosing. Considerable amounts of free hydrated ions $\mathrm{Co}_{\text {aq. }}{ }^{2+3+}$ in tissue could be expected especially in those cases, when the radionuclide is not firmly engaged by the chelate kit.

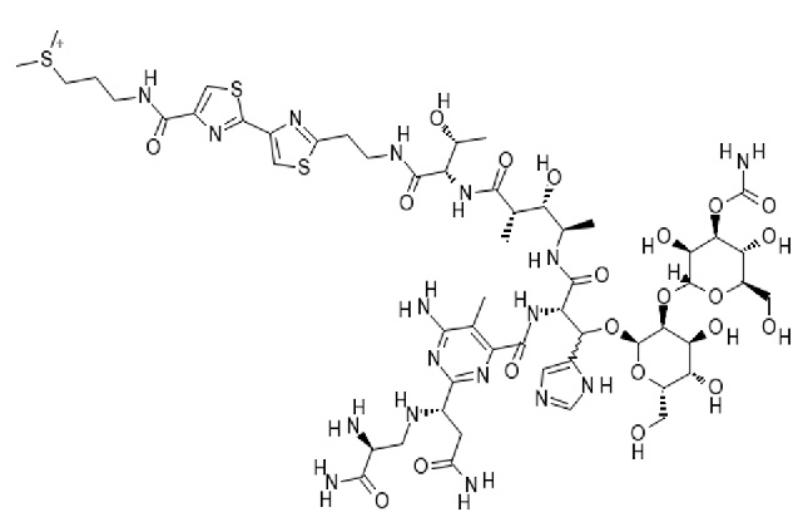

Fig. 1. Bleomycin $A_{2}$, a glycosylated linear nonribosomal peptide antibiotic, often radiolabeled with Co-57 for tumor radiodiagnosis.

Understanding the behavior of uncomplexed Cobalt ions in aqueous solutions at microconcentrations levels is essential in order to avoid incidents in radioclinical practice. Investigations on properties of $\mathrm{Co}^{\mathrm{n}+}$ species at 
microconcentrations levels should be made by appropriate techniques regarding the well-known fact, that there are serious differences in behavior of radioisotope in trace, $\mu \mathrm{M}$ and $\mathrm{mM}$ amounts. The specific feamtures of microconcentrated radioactive solutions are being usually connected to formation of pseudocolloids as well as polymer associates $(6,10,11)$. Thus, electrochemical methods as electrophoresis, electromigration, transference numbers and potentiometric analysis are extremely suitable, offering a tracer working concentrations down to $10^{-10}-10^{-11} \mathrm{M}$. Moreover, these methods guarantee a unique, direct measurement of basic thermodynamic parameters, such as ion velocity, diffusion and electrodiffusion rates (4). Most reliable results can be retrieved by the method of horizontal zone electrophoresis in free electrolyte systems, by which a major part of side effects (electroosmosis, rheophoresis, phase equilibrium etc.) are avoided (2).

\section{MATERIALS AND METHODS}

Experimental part of this work was done at the Joint Institute for Nuclear Research (JINR) - Dubna, Russia, in the Flerov Laboratory of Nuclear Reactions (FLNR) and Djelepov Laboratory of Nuclear Problems (DLNP).

A carrier-free ${ }^{57} \mathrm{Co}\left(\mathrm{T}_{1 / 2}=271,7 \mathrm{~d}, \mathrm{E}_{\gamma}=14,4 \mathrm{keV}(9,19 \%)\right.$, $122,1 \mathrm{keV}(85,6 \%), 136,5 \mathrm{keV}(10,7 \%))$ (19) with high specific activity was used. Available isotope ${ }^{60} \mathrm{Co}\left(\mathrm{T}_{1 / 2}=\right.$ $5,27 \mathrm{y}, \mathrm{E} \gamma=1173,2 \mathrm{keV}(100 \%), 1332,5 \mathrm{keV}(100 \%))(19)$ is not preferred because of its very high-energy gamma rays. Efficiency of collimator unit used dramatically falls if rising energy of gamma rays being detected, which can be easily proven by scanning two identical by shape radioactive sources of soft- and, respectively, hard-gamma ray spectrum. As it is shown on Fig. 2, a $\varnothing 3 \mathrm{~mm}$ soft gamma emitter (Am-241) appears to be only $6 \mathrm{~mm}$ dot, while similar $\varnothing 3 \mathrm{~mm}$ hard gamma emitter (Co-60) is detected as 26 mm region.

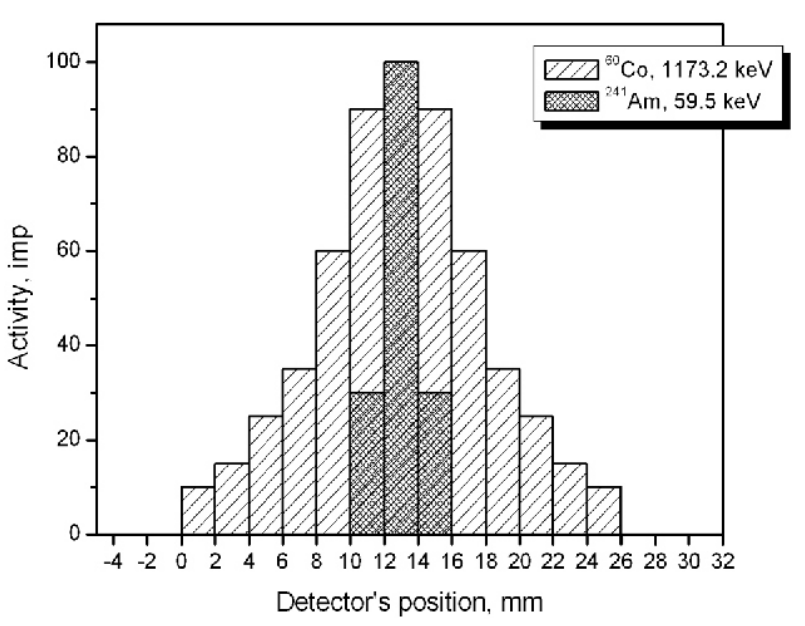

Fig. 2. Efficiency of collimator unit. Two dot-shaped $(\emptyset 3 \mathrm{~mm})$ standardized gamma ray sources are independently scanned. Linear step of detector unit is 2
The electromigration analysis was done by fully automated device for horizontal zone electrophoresis in a free electrolyte (7). In each separate experiment $5-10 \mu \mathrm{Ci}^{57} \mathrm{Co}$ was being injected into the migration tube, filled with an appropriate electrolyte system. In this way into the migration cell a 2 $\mu \mathrm{l}$ radioactive cylindrical zone was being formed. Concentration of the radioisotope within the zone was about $10^{-6}$ $\mathrm{M}$. The temperature of the electrolyte was set to desired value and maintained constant with an accuracy of $0,05^{\circ} \mathrm{C}$; $\mathrm{pH}$ of the solution was set and measured with an accuracy of 0,05. Bidistilled water as well as chemical reagents of grade "purissimum" and Suprapur ${ }^{\circledR}$ Merck $^{\circledR}$ were used. The gradient of the electric field was $10,0 \mathrm{~V} \cdot \mathrm{cm}^{-1}$ and maintained uniform with an accuracy of $0,03 \mathrm{~V} \cdot \mathrm{cm}^{-1}$.

Collected experimental data were mathematically processed using numerical methods by means of specialized software - Equilibrium (1) and Microcal ${ }^{\mathrm{TM}}$ Origin $^{\circledR}$ (18).

\section{RESULTS AND DISCUSSION}

A cycle of well-planned electrophoretic experiments was done. In each separate experiment four specific radioactive zone parameters are traced: direction of movement, form, width and velocity. Direction of movement reveals the sign of a ions charge; geometrical parameters and their stability shows the presence or absence of side interactions (adsorption, hydrolysis and pseudocolloid formation); velocity itself appears to be the base quantitative electrochemical characteristic of the ion being investigated. By the help of the existing electromigration methodic (2) ion velocity can be used to derive information about important physico-chemical ion characteristics, such as ion mobility, relative ion conductance, Stocks radius, molar volume, hydration number as well as diffusion coefficient into particular experimental conditions.

\section{Determining the Cobalt ion mobility}

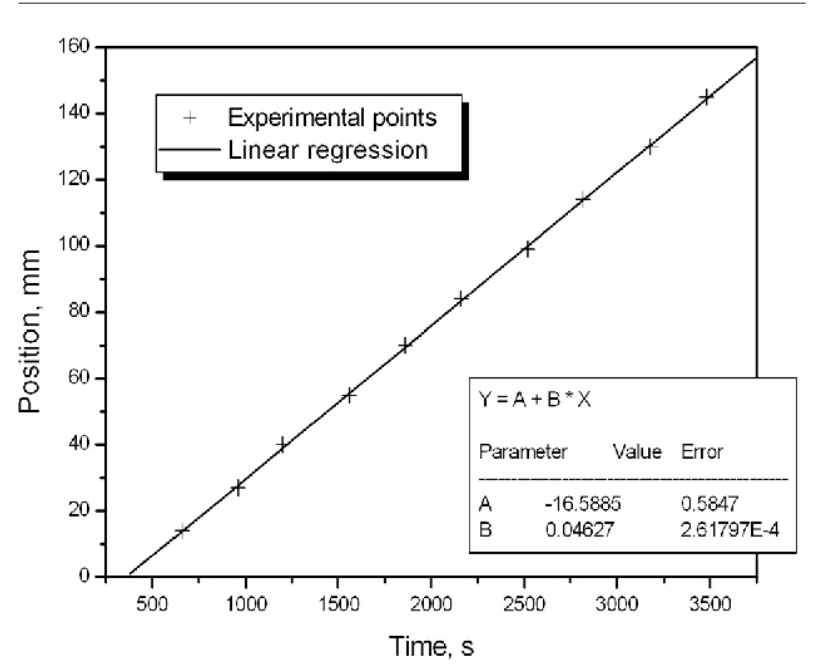

Fig. 3. Determining the Cobalt ion mobility at $20,0^{\circ} \mathrm{C}$. 
In each experiment, after injection of the radionuclide the electric field has been switched on, which results to electrophoretic traveling of the zone. Periodically, the position of the zone (here: the maximum zone activity) has been determined, tracing in such a way its movement along the tube. Since the ions in uniform electric field migrate with a constant velocity, there should be a linear correlation between the time and position of the zone. Results can be used to find out the ion velocity, and, consequentially, ion mobility, as it is shown on Fig. 3 and Fig. 4. Both experiments were done using a perchlorate medium $\left(\mathrm{NaClO}_{4} / \mathrm{HClO}_{4}\right)$ due to poor hydration and complex-forming ability of $\mathrm{ClO}^{4}$. Conditions were as follows: ionic strength $\mu=0,0020 \mathrm{~mol}^{-1}{ }^{-1}$, $\mathbf{p H}=3,16$, gradient of electric field $\Delta \mathbf{E}=10,00 \mathrm{~V} \cdot \mathrm{cm}^{-1}$. The only difference between these two separate experiments were the temperature of the electrolyte system (20,0 ${ }^{\circ} \mathrm{C}$ and $25,0{ }^{\circ} \mathrm{C}$ respectively), fact, which will be used later to determine some parameters' temperature dependence.

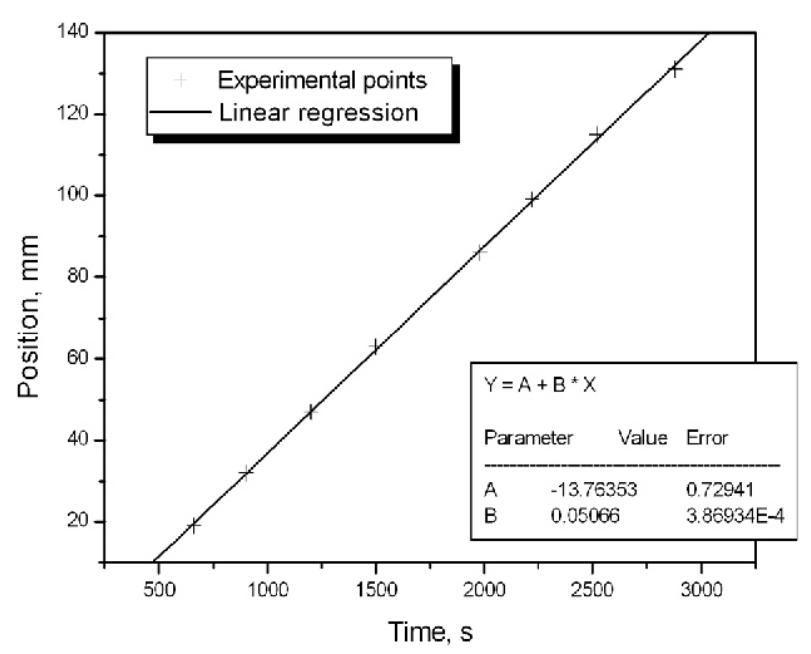

Fig. 4. Determining the Cobalt ion mobility at $25,0^{\circ} \mathrm{C}$.

The values obtained for the hydrated Cobalt (II) absolute ion velocity are:

at $20,0{ }^{\circ} \mathrm{C}:(4,63 \pm 0,03) \cdot 10^{-3} \mathrm{~cm} \cdot \mathrm{s}^{-1}$ and

at $25,0^{\circ} \mathrm{C}:(5,07 \pm 0,04) \cdot 10^{-3} \mathrm{~cm} \cdot \mathrm{s}^{-1}$, respectively.

These results can be used to calculate the values of ion mobility in each of the cases:

at $20,0{ }^{\circ} \mathrm{C}:(4,63 \pm 0,03) \cdot 10^{-4} \mathrm{~cm}^{2} \cdot \mathrm{V}^{-1} \cdot \mathrm{s}^{-1}$ and

at $25,0^{\circ} \mathrm{C}:(5,07 \pm 0,04) \cdot 10^{-4} \mathrm{~cm}^{2} \cdot \mathrm{V}^{-1} \cdot \mathrm{s}^{-1}$, respectively.

It has been detected that Cobalt zone migrates to the anode showing a strictly constant speed and keeping its initial narrow, regular Gauss-shaped form. Hence, one can conclude that the zone consists of cations $\mathrm{Co}_{\mathrm{aq}}{ }^{\mathrm{n}+}$ which were not engaged in side processes as hydrolysis and adsorption to the inner cell's surface, therefore the values obtained should be an adequate ones. Moreover, comparing these results with the values of ion mobility of other hydrated cations in the very same condition, e.g. $(6,86 \pm 0,05) \cdot 10^{-4} \mathrm{~cm}^{2} . \mathrm{V}^{-1} \cdot \mathrm{s}^{-1}$ for $\mathrm{Tm}_{\mathrm{aq}}{ }^{3+}(16),(6,20 \pm 0,10) \cdot 10^{-4} \mathrm{~cm}^{2} \cdot \mathrm{V}^{-1} \cdot \mathrm{s}^{-1}$ for $\mathrm{Yb}_{\mathrm{aq}}{ }^{3+}$ and $(6,21 \pm 0,10) \cdot 10^{-4} \mathrm{~cm}^{2} \cdot \mathrm{V}^{-1} \cdot \mathrm{s}^{-1}$ for $\mathrm{Lu}_{\mathrm{aq}}{ }^{3+}(2)$, one can con- clude that the charge of Cobalt ions in both experiments should be $2+$, as the proportional factor is near $2 / 3$.

Ion mobility, measured in the electrolyte solutions with a different ionic strength, shows different values, which is in agreement to the Onzager's limiting low (4):

$$
u=u_{0}-A \cdot \mu^{\frac{1}{2}}
$$

where $\mathbf{u}$ - ion mobility, $\mathrm{cm}^{2} \cdot \mathrm{V}^{-1} \cdot \mathrm{s}^{-1}, \mathbf{u}_{0}-$ ion mobility at infinite dilution, $\mathrm{cm}^{2} \cdot \mathrm{V}^{-1} \cdot \mathrm{s}^{-1}, \mu-$ ionic strength, mol. $1^{-1}, \mathbf{A}-$ an empiric factor $\left(\mathbf{A} \approx 5,5 \pm 0,05\right.$ for cations $\left.\mathrm{Me}^{2+/ 3+}(16)\right)$. Applying this equation toward the found results we obtain for the $\mathrm{Co}_{\mathrm{aq}}{ }^{2+}$ ion mobility at infinite dilution following values:

at $20,0{ }^{\circ} \mathrm{C}:(4,88 \pm 0,06) \cdot 10^{-4} \mathrm{~cm}^{2} \cdot \mathrm{V}^{-1} \cdot \mathrm{s}^{-1}$ and at $25,0{ }^{\circ} \mathrm{C}:(5,32 \pm 0,06) \cdot 10^{-4} \mathrm{~cm}^{2} \cdot \mathrm{V}^{-1} \cdot \mathrm{s}^{-1}$, respectively, which is in accordance to the reference data: $\mathbf{u}_{0}\left(\operatorname{Ln}^{3+}\right)=$ $(6,6 \div 7,0) \cdot 10^{-4} \mathrm{~cm}^{2} \cdot \mathrm{V}^{-1} \cdot \mathrm{s}^{-1}(3)$, taking into account the difference between ions charge. These data can be used to predict Cobalt ion mobility (and all related parameters) in vast variety of electrolyte systems.

\section{Determining the Co ${ }_{a q .}{ }^{2+}$ temperature coefficient}

Ion mobility (and all related parameters) grows as temperature increase by the factor of nearly $2 \%$ per $1^{\circ}(9)$. More strictly, the relation between ion mobility and temperature (T, K) can be given as (14):

$$
\mathbf{u}\left(\mathbf{T}_{2}\right)=\mathbf{u}\left(\mathbf{T}_{1}\right)\left[1+\alpha\left(\mathbf{T}_{2}-\mathbf{T}_{1}\right)\right]
$$

where $\alpha$ - temperature coefficient of first order, $\mathrm{deg}^{-1}$. As we have already determined $\mathrm{Co}_{\mathrm{aq} .}{ }^{2+}$ ion mobility at two different temperatures, calculation of temperature coefficient for this hydrated ion could be now done:

$$
\alpha=0,0190 \text {, }
$$

and its value is very close to the expected one, as it has been mentioned above. This exact value can be used to predict Cobalt ion mobility (and all related parameters) in close temperature range near $25^{\circ} \mathrm{C}$.

\section{Determining the $\mathrm{Co}_{\text {aq. }}{ }^{2+}$ equivalent conductance}

One of the most conventional electrochemical parameter is ion equivalent conductance $\lambda, \mathrm{m}^{2} \cdot \Omega^{-1} \cdot \mathrm{mol}^{-1}$. Its value is often used as a result of routine electrophoretic analysis and plays a major role in physico-chemical investigations. There is a simple relation between л and ion mobility $\mathbf{u}(9)$ :

$$
\lambda=\mathbf{F} . \mathbf{u}
$$

where $\mathbf{F}=96485{\mathrm{C} . \mathrm{mol}^{-1}}^{-1}$ is a Faraday constant. According to this equation we have calculated values of $\mathrm{Co}_{\mathrm{aq}}{ }^{2+}$ equivalent conductance to be as follows: at $25,0{ }^{\circ} \mathrm{C}:(4,89 \pm 0,04) \cdot 10^{-3} \mathrm{~m}^{2} \cdot \Omega^{-1} \cdot \mathrm{mol}^{-1}$. 
Extrapolation to ionic strength zero leads to equivalent conductance at infinite dilution value

$\lambda_{0}=(5,13 \pm 0,05) \cdot 10^{-3} \mathrm{~m}^{2} \cdot \Omega^{-1} \cdot \mathrm{mol}^{-1}$. Comparison with the reference data $5,20.10^{-3} \mathrm{~m}^{2} \cdot \Omega^{-1} \cdot \mathrm{mol}^{-1}$ for $\mathrm{Ni}^{2+}$ and 5,40 $\mathrm{m}^{2} \cdot \Omega^{-1} \cdot \mathrm{mol}^{-1}$ for $\mathrm{Fe}^{2+}(5)$ shows an extremely good rate of agreement. Knowing the value of temperature coefficient for the hydrated Cobalt ion, one can easily do estimations for temperatures, others than $25^{\circ} \mathrm{C}$.

\section{Determining the Co ${ }_{a q .}{ }^{2+}$ Stocks radius}

The Stocks radius $\mathbf{r}_{\mathbf{s}}$ of ions gave us extremely useful information about the state of the ion in dissolute form and can be used for characterization of its hydration shell (8). Although attention should be drawn to the fact, that the electrotransport methods are practically unique in describing kinetically stabile ion formations $(4,13)$. For calculation of the Stocks radii a Stocks relation can be used (9):

$$
\mathbf{r}_{\mathbf{s}}=\mathbf{Z e} /(6 \pi \eta \mathbf{u})
$$

where $\mathbf{Z}$ is the absolute charge of the ion, $\mathbf{e}=1,602.10^{-19} \mathrm{C}$ is electron charge, $\eta$ is the dynamic viscosity of solution (for a dilute water systems at $25{ }^{\circ} \mathrm{C} \eta \approx 0,000895$ Pa.s). Having values of Cobalt (II) ions mobility determined, we have calculated Stocks radius for the hydrated $\mathrm{Co}$ (II) ion as follows:

at $25,0^{\circ} \mathrm{C}: 3,7 \pm 0,1 \AA$.

Extrapolation to ionic strength zero leads to value $\mathbf{r}_{\mathbf{s}}^{\mathbf{0}}=3,6$ $\pm 0,1 \AA$. Reference value found for comparison: $\mathbf{r}_{\mathbf{s}}{ }^{\mathbf{s}}\left(\mathrm{Zn}_{\mathrm{aq}}{ }^{2+}\right)=3,5 \AA$ (12). However, all this values should be corrected, as it is known that Stocks relation (4) looses its linearity beneath approximately $4 \AA$ (12). The correction method is also described in reference cited. Finally, we have obtain followed values for hydrated $\mathrm{Co}_{\mathrm{aq}}{ }^{2+}$ ion:

$$
\begin{aligned}
& \mathbf{r}_{\mathbf{s}}=4,7 \pm 0,1 \AA \text { and } \\
& \mathbf{r}_{\mathbf{s}}^{\mathbf{0}}=4,5 \pm 0,1 \AA .
\end{aligned}
$$

Reference corrected value for comparison: $\mathbf{r}_{\mathbf{s}}{ }^{0}\left(\mathrm{Zn}_{\mathrm{aq} .}{ }^{2+}\right)=4,4$ $\AA$ (12), which shows an excellent agreement with our data.

\section{Determining the Co ${ }_{a q .}{ }^{2+}$ absolute and molar volumes}

The absolute ion volume $\mathbf{V}_{\mathbf{s}}$ as well as the molar ion volume $\mathbf{V}_{\mathbf{s}}^{\mathbf{0}}$ are important parameters, significant for the solutions' structure investigation. They could be connected to the Stocks radius $\mathbf{r}_{\mathbf{s}}$ by the following equations (4):

$$
\begin{aligned}
& \mathbf{V}_{\mathbf{s}}=4 / 3 \cdot \pi \mathbf{k r s}^{3} \\
& \mathbf{V}_{\mathbf{s}}^{\mathbf{0}}=4 / 3 \cdot \mathbf{N}_{\mathbf{A}} \pi \mathbf{k r s}^{3},
\end{aligned}
$$

where $\mathbf{N}_{\mathbf{A}}=6,022.10^{23} \mathrm{~mol}^{-1}$ is the Avogadro constant and $\mathbf{k}$ - packaging factor (for a simple hydrated ions $\mathbf{k}=1$ ). Using the value obtained for the $\mathrm{Co}_{\mathrm{aq}}{ }^{2+}$ Stocks radius we have calculated absolute volume and molar volume of the hydrated Cobalt (II) ion, respectively, as follows:

$$
\begin{aligned}
& \mathbf{V}_{\mathbf{s}} \approx 380 \AA^{3} \text { and } \\
& \mathbf{V}_{\mathbf{s}}^{\mathbf{0}} \approx 2,3 \cdot 10^{26} \AA^{3} \cdot \mathrm{mol}^{-1} .
\end{aligned}
$$

Reference data for comparison shows the absolute volume of the $\mathrm{Zn}_{\mathrm{aq}}{ }^{2+}$ equal to $360 \AA^{3}(12)$.

\section{Determining the $\mathrm{Co}_{a q .}{ }^{2+}$ hydration number}

Comparing the Stocks $\mathbf{r}_{\mathbf{s}}$ and the crystallographic $\mathbf{r}_{\mathbf{k}}$ radii of the given ion one can estimate the ion hydration number $\mathbf{n}_{\mathbf{s}}-$ the mean amount of water molecules, coordinated to the solvated ion. Described estimation could be done by the following equation (4):

$$
\mathbf{n}_{\mathbf{s}}=4 / 3 . \pi\left(\mathbf{r}_{\mathbf{s}}^{3}-\mathbf{r}_{\mathbf{k}}^{3}\right) / \mathbf{V}_{\mathbf{L}},
$$

where $\mathbf{V}_{\mathbf{L}}$ is the solvent's molecule volume (for the water corresponding value is approximately $30 \AA^{3}$ ). Crystallographic radius for the $\mathrm{Co}^{2+}$ is known to be approximately $0,82 \AA$ (5). Hence, the value of the hydration number of $\mathrm{Co}^{2+}$ into the investigated solutions we have found to be 12-13. For comparison, hydration number for the $\mathrm{Zn}^{2+}$ in diluted aqueous systems has been reported to be approximately 12 (12). Relatively high value of $\mathrm{Co}^{2+}$ hydration number clearly proves the expected tendency for Cobalt (II) ions to suffer deep hydration.

\section{Determining the $\mathrm{Tm}^{3+}$ diffusion coefficient}

The most important kinematical ion parameter appears to be its coefficient of diffusion. Though there is developed techniques for its measurement, most of them are complicated, need a long experimental cycles and are applicable for the specialized aims only. However, it is possible to find out an estimation of the diffusion coefficient, using the Nernst-Einstein low, which gives a connection between micro-kinematical properties of the ion (such as ion mobility) and its macro-features (diffusion coefficient) (9):

$$
\mathbf{D}=\mathbf{u R T} / \mathbf{Z F}
$$

where $\mathbf{D}$ is the coefficient of diffusion, $\mathrm{cm}^{2} \cdot \mathrm{s}^{-1}, \mathbf{T}$ - temperature, $\mathrm{K}$, and $\mathbf{R}=8,314 \mathrm{~J} \cdot \mathrm{mol}^{-1} \cdot \mathrm{K}^{-1}$ is the universal gas constant. Strictly, the Nernst-Einstein low is obeyed in infinitely diluted solutions only; nevertheless an accuracy of $10-15 \%$ is often achieved for real solutions (9).

Using the Nernst-Einstein low we have found the diffusion coefficient of the $\mathrm{Tm}_{\mathrm{aq}}{ }^{3+}$ in investigated solutions to be as follows: at $25,0^{\circ} \mathrm{C}: 6,5 \cdot 10^{-6} \mathrm{~cm}^{2} \cdot \mathrm{s}^{-1}$.

Unfortunately, there are no reference data for comparison available, however, the found result seems to be a reasonable one, taking into account that values of simple cations' diffusion coefficients in diluted aqueous solutions can usually be found within the range of $2-10.10^{-6} \mathrm{~cm}^{2} \cdot \mathrm{s}^{-1}(2)$.

\section{CONCLUSION}

In order to understand the specific chemical behavior of Cobalt species in diluted aqueous solution, a set of electrochemical experiments were carried out. A highly suitable device for a horizontal zone electrophoresis in a free elec- 
trolyte systems as well as an existing methodic for the electrochemical analysis were used. As a result, the most important physico-chemical properties of the hydrated $\mathrm{Co}$ (II) ions have been determined by significant accuracy. It has been shown, that in ultradiluted (mM range) water solutions $\mathrm{Co}_{\mathrm{aq}}{ }^{2+}$ reports to be a small, heavily hydrated cation with typical features as thick solvate shell and considerable affinity for hydrolysis. Thus, stability of Cobalt complexes used in nuclear medicine may not be sufficient to fully avoid the risk of emitting the free $\mathrm{Co}^{2+}$ ions in blood and body tissue. Moreover, it is expected that radioactive complex Cobalt drugs shows a tendency for decomposition due to autoradiolytic processes. Products of $\mathrm{Co}$ (II) hydrolysis are mainly insoluble Cobalt hydroxides $\mathrm{Co}(\mathrm{OH})_{2}(\mathrm{aq})_{\mathrm{x}}$ and Cobalt hydroxy-halides $\mathrm{Co}(\mathrm{OH}) \mathrm{Hal}(\mathrm{aq})_{\mathrm{x}}$, which can be easily precipitated onto the vessel surfaces (especially when in microamounts), what obviously can not be allowed during in-vivo treatment. Hence, it could be recommended a use of polydentate ligands as a Cobalt carriers (where biochemical properties are suitable), according the extremely high stability constant of their metal-chelate complexes. Adding to the kit a small amounts of typical ligands of polyaminopolycarboxylic acid family (such as EDTA and DTPA) as a satellite safeguards should be discussed either.

\section{REFERENCES}

1. Бончев, Г., Божиков, Г., Иванов, П., Маслов, О. и др. Программа расчета "Equilibrium" для подготовки и анализа водных растворов. Сообщение ОИЯИ Р12-2003-75, Дубна, 2003

2. Бончев, Г. Апаратура за хоризонтална зонна електрофореза в свободен електролит. Методика на миграционния експеримент. Докторска дисертация, БАН, София, 2003

3. Добош Д. Электрохимические константы. Мир, Москва, 1980

4. Крестов, Г., Новоселов, Н., Перелыгин, И. и др. Ионная сольватация. Наука, Москва, 1987

5. Лурье, Ю. Справочник по аналитической химии, Химия, Москва, 1989

6. Несмеянов, А. Радиохимия. Химия, Москва, 1978

7. Приёмышев, А., Бончев, Г., Божиков, Г., и др. Установка для горизонтального зонного электрофореза в свободном электролите. Сообщение ОИЯИ Р13-2000-43, Дубна, 2000

8. Робинсон, Р., Стокс, Р. Растворы электролитов. Изд. иностр. лит., Москва, 1963

9. Степанов, А., Корчемная, Е. Электромиграчионный метод в неорганическом анализе, Химия, Москва, 1979
10. Тельдеши, Ю. Радиоаналитическая химия. Энергоатомиздат, Москва, 1987

11. Фридландер, Г., Кенеди, Д., Милър, Д. Ядрена химия и радиохимия. Наука и изкуство, София, 1970

12. Шведов, В. (ред.) Электромигариионный метод в физико-химических и радиохимических исследованиях. Атомиздат, Москва, 1971

13. Энтелис, С., Тигер, Р. Кинетика реакций в жидкой фазе. Химия, Москва, 1973

14. Эрдей-Груз, Т. Явления переноса в водных растворах электролитов, Мир, Москва, 1977

15. Bese, N., Kiel, K., E1-Gueddari, B., Campbell, O., Awuah, B., Vikram, B. Radiotherapy for breast cancer in countries with limited resources: program implementation and evidence-based recommendations, The Breast Journal, 12, Supplement 1, 2006, pp. S96-S102

16. Bontchev, G., Bojikov, G., Ivanov, P. Tm-167: an electrophoretic investigation on the properties in the ultradiluted aqueous solutions. Scripta Scientifica Medica, Medical University - Varna, 36, 2004, pp. 21-24

17. Classen, J., Hehr, T., Paulus, W., Plate, K., Bamberg, M. Suprasellar melanocytoma: a case of primary radiotherapy and review of the literature, $J$. of Neuro-Oncology, 58, No 1, 2002, pp. 39-46

18. Microcal ${ }^{\mathrm{TM}}$ OriginT Version 6.0. Microcal Software, Inc. Northampton USA. Copyright 1991-1999 (http://www.microcal.com)

19. National Nuclear Data Center, Brookhaven National Laboratory, Nuclear data sheets (http://www.nndc.bnl.gov)

20. van de Poll, M., Versluis, A., Rasker, J., Jurjens, H., Woldring M. Labelling of bleomycin with cobalt-57, indium-111, technetium-99m, mercury-197, lead-203, and copper-67, Nuklearmedizin, 15 (2), 1976, pp. 86-90

21. Roberts, T. Cold pasteurization of food by irradiation, Virginia State University, Pub. No. 458-300, 1998

22. Ruszczak, Z., Stadler, R., Schwartz, R. Kaposi's sarcoma limited to penis treated with cobalt-60 radiotherapy, J. med., 27, No 3-4, 1996, pp. 211-220

23. Schilling, R. Intrinsic factor studies II. The effect of gastric juice on the urinary excretion of radioactivity after the oral administration of adioactive vitamin B12, J. Lab. Clin. Med., 42, 1953, pp. 860-865.

24. Schindler, E., Kretzschmar, K., Aulich, A., Wende, S., Kutzner, J. Serial CT studies of a metastatic pinealoma with reference to the radiotherapeutic problems, J. Neuroradiology, 14, No 3, 1977, pp. 127-132 